DOI: 10.46340/eppd.2020.7.3.28

Dmytro Piestruiev

ORCID ID: https://orcid.org/0000-0001-6832-3656

National University "Odesa Law Academy", Ukraine

\title{
UNDERSTANDING OF THE CONCEPT \\ "WITHOUT MANDATE" IN THE JUDICIAL PRACTICE OF POLAND AND UKRAINE WHEN CONSIDERING NEGOTIORUM GESTIO CASES
}

\author{
Дмитро Пєструєв \\ Національний університет «Одеська юридична академія», Україна \\ РОЗУМІННЯ КАТЕГОРЇ̈ «БЕЗ ДОРУЧЕННЯ» \\ У СУДОВІЙ ПРАКТИЦІ ПОЛЬЩІ І УКРАЇНИ \\ ПРИ РОЗГЛЯДІ СПРАВ NEGOTIORUM GESTIO
}

The article makes a comparative analysis and studies the understanding of one of the prerequisites and characteristic traits of the institute of management of affairs without mandate - the category "without mandate" - in the judicial practice of Poland and Ukraine. This category is considered as a prerequisite for the emergence of relations of management of another's affairs without mandate and as one of the main features of the relations under consideration. The concepts of legal title and situations in which a person can intrude into the sphere of other people's property interests without any legal basis are analyzed. A comparative study of the "without mandate" category was made on the basis of judicial practice in Ukraine and Poland. It is concluded that the interpretation of this category by the judicial authorities of both countries belonging to the same legal family is similar.

Keywords: management of affairs without mandate, negotiorum gestio, legal title, judicial practice, intrusion, for the benefit of a principal.

Актуальність. Постановка проблеми. У сучасних умовах зростання уваги до забезпечення і захисту прав та інтересів людини, розвитку громадянського суспільства суттєво змінюється роль правових інститутів, що мають стимулювати громадську активність, одночасно вберігаючи інтереси приватної особи від втручання сторонніх у цю сферу. Зокрема, цими обставинами зумовлюється зростання значення дослідження правового регулювання та практики застосування відповідних норм стосовно ведення чужих справ без доручення, котре є одним з найбільш типових випадків правової колізії, що виникає при правомірному втручанні усферу чужих майнових інтересів. До цього варто додати, що в умовах сучасних інтеграційних процесів особливої актуальності набуває вивчення досвіду інших країн у цій галузі, що дає можливість обрання оптимальних рішень для вдосконалення вітчизняного цивільного законодавства.

Аналіз останніх досліджень і публікацій, в яких започатковане вирішення проблеми. В польській юридичній літературі питанням ведення чужих справ без доручення присвячували свої наукові праці Piotr Drapała ${ }^{1}$, Joanna Kruszyńska- Kola ${ }^{2}$ Jan Hajberda ${ }^{3}$, W. Ludwiczak ${ }^{4}$, та інші, нечисленні науковці. В Україні уваги даному інституту приділялося трохи більше. Так, у різний час

\footnotetext{
${ }^{1}$ Drapała, P. (2010). Prowadzenie cudzych spraw bez zlecenia. Warszawa: Konstrukcja prawna.

${ }^{2}$ Kruszyńska-Kola, J. (2016). Prowadzenie cudzych spraw bez zlecenia jako wyraz zachowań altruistycznych. Ruch prawnyczy, ekonomiczny i socjologiczny, LXXYIII, 1.

${ }^{3}$ Hajberda, J. (2005). Koncepcja prowadzenia cudzych spraw bez zlecenia w kodeksie zobowiązań z 1933 roku na tle wcześniejszych rozwiązań europejskich. Czasopismo prawno-hystoryczne (Kraków), LVII, 1.

${ }^{4}$ Ludwiczak, W. (1960). Prowadzenie cudzych spraw bez zlecenia. Wybrane zagadnienia. Warszawa.
} 
ці питання досліджували Стависский П.Р. ${ }^{1}$, Боброва Д.В. ${ }^{2}$, Харитонов С.О. ${ }^{3}{ }^{4}$, Зубар В.М. ${ }^{5}$ та інші. Однак, дослідження окремих аспектів negotiorum gestio, особливо в світлі судової практики, не було предметом дослідження. Відповідні дослідження започаткував автор статті у своїх попередніх публікація $\mathrm{x}^{6}, 7,8$. Тим більше, відсутні порівняльно-правові дослідження тлумачення категорії «без доручення» у судовій практиці України та Польщі. Зазначеним і обумовлена актуальність теми статті і доцільність звернення до неї автора.

Метою статті є порівняльний аналіз розуміння однієї з передумов і характерних рис інституту ведення чужих справ без доручення - категорії «без доручення»- у судовій практиці Польщі та України.

Завданнями статті є з'ясування правової природи, поняття категорії «без доручення» при negotiorum gestio i iіi тлумачення при розгляді справ відповідної категорії у судах Польщі та України. Встановлення подібних рис та розбіжностей.

Виклад основного матеріалу. Ведучи мову про ведення чужих справ без доручення, слід звернути увагу на те, що визначення відповідних зобов'язань у Цивільному кодексі Польщі відсутнє. Натомість, його стаття 752 містить загальне правило, згідно якому той, хто веде чужу справу без доручення, повинен діяти на користь особи, справу якої він веде, і відповідно до його вірогідної волі, виявляючи при цьому при веденні справ належну турботу (дбайливість) про них.

Грунтуючись на положеннях наведеної статті, можна зробити висновок, що ведення чужих справ без доручення $є$ підставою виникнення зобов'язань між особою, яка веде чужу справу без доручення та особою, справу якої веде діюча особа. При цьому пріоритет надається інтересам особи, справу якої веде особа, що діє без доручення «хазяїна справи». Це випливає, на нашу думку, з того, що у наведеній статті Цивільного кодексу Польщі вимоги висуваються саме до того, хто веде чужу справу без доручення: він повинен діяти на користь особи, справу якої веде, не маючи на те доручення; він повинен вести чужу справу відповідно до вірогідної волі особи, чиї справи веде; він повинен виявляти при веденні чужої справи належну турботу про цю справу. При цьому про якісь права того, хто веде чужу справу без доручення, тут, навіть, не згадується.

Насамперед, польські законодавці розглядають ведення справ без доручення як підставу виникнення нібито договірних зобов'язань. Такий висновок підтверджується й тим, що згідно ст.756 Цивільного кодексу Польщі схвалення (підтвердження) особою, справи якої велись, надає веденню чужих справ характеру договору доручення.

Як зазначають польські науковці, метою врегулювання відносин ведення чужих справ без доручення $є$ відхід від принципу втручання без належного уповноваження, в права інших осіб. Винятком 3 невтручання в чужі справи є складні та неочікувані, непередбачувані обставини, коли треті особи, діючи спонтанно, з альтруїстичних міркувань, можуть захистити інших

\footnotetext{
${ }^{1}$ Стависский, П. Р., Харитонов, Е.О. (1979). Обязательства из ведения дел без поручения и некоторые смежные обязательства в советском гражданском праве. Проблемы социалистической законности, 4, 104-111. 2 Боброва, Д. (1997). Недоговірні зобов’язання у проекті Цивільного кодексу України 1996 р. Українське право, 3, 180.

${ }_{3}^{3}$ Харитонов, Е. О. (1980). Обязательства, возникающие из ведения дел без поручения, в советском гражданском праве: автореферат диссертации на соискание научной степени кандидата юридических наук. Одесса: ОГУ имени И. И. Мечникова.

${ }^{4}$ Харитонов, С. О. (2014). Система зобов'язань, що виникають внаслідок відвернення шкоди, за Цивільним кодексом України. Актуальні проблеми приватного права України: Збірник статей до ювілею доктора юридичних наук, професора Наталії Семенівни Кузнєиової, 461-480.

5 Зубар, В. М. (2001). Зобов'язання, що виникають з ведення чужих справ без доручення: дисертаиія на здобуття наукового ступеня кандидата юридичних наук. Київ: НАН України Інститут держави і права імені В.М. Корецького.

${ }^{6}$ Пеструєв, Д. М. (2017). Регулювання ведення чужих справ без доручення у цивільному законодавстві Польщі. Науково-практичний журнал Часопис иивілістики, 25, 57-62.

${ }^{7}$ Пеструєв, Д. М. (2019). Формування концепції правового регулювання ведення справ іншої особи без ії доручення в Україні та Польщі. Науково-практичний журнал Часопис иивілістики, 25, 41-47.

${ }^{8}$ Пеструєв, Д. М. (2018). Психологічна основа ведення чужих справ без доручення у польському праві. Шерешевські читання «Проблеми цивільно-правового захисту прав власників у сучасних умовах інтеграиійного розвитку України»: матеріали всеукраӥнської науково-практичної конференції, присвяченої 85-річчю академіка В.В. Луия (Одеса, 7 грудня 2018 року). Одеса: Фенікс, 75-78.
} 
від загрожуючих небезпек або поліпшити їх попереднє правове становище. При цьому одразу йдеться про конфлікт двох цінностей: з одного боку - невтручання в справи іншої особи, з іншого можливості (допущення) надання допомоги особі, котра не може діяти сама.

Інститут negotiorum gestio $€$ спробою визначення меж обох цінностей (засад), що мають важливе значення, і розв'язання проблем, що при цьому виникають. В результаті зваження обох цінностей законодавець або забороняє втручання, трактуючи ведення чужих справ без доручення лише як скромний виняток, або допускає ширше застосування цієї інституції, намагаючись, однак, тримати іiі у розсудливих межах, протидіючи в такий спосіб допомозі, що тягне негативні наслідки. Найчастіше законодавець прагне, регулюючи ведення чужих справ без доручення, заохочення потенційних волонтерів до надання допомоги, встановлюючи, що діяльність з чинників альтруїстичних $є$ природним і позитивним проявом суспільного життя ${ }^{1}$.

Істотним $\epsilon$ визначення значення терміну «ведення справи», а також визначення (встановлення), коли справа «є чужою», а надто, яке значення має формулювання «без доручення». Польський законодавець не визначив зазначених понять ні в кодексі зобов'язань 1933 року, ані в Цивільному кодексі Польщі 1964 року.

Назва інституції безпосередньо вказує на діяльність «без доручення». Науковці-правники були солідарні в тому, що гіпотеза норм про ведення чужих справ без доручення стосувалася будь-якої діяльності без відповідного правового повноваження - як явного, так і такого, що припускається. Джерелом юридичного закріплення повноваження міг бути закон (уповноваженим був, наприклад, батько, чоловік, партнер), рішення суду (наприклад, опікун, піклувальний, радник), довіреність, доручення. В зв'язку з тим, що метою інституції ведення чужих справ без доручення було забезпечення прав і обов'язків домінуса а також діючого зальтруїстичних намірів гестора, negotiorum gestio не підлягало застосуванню у випадках втрати законної сили повноваження, що виникало exlege, на подальше виникнення якого гестор, наприклад, опікун, не мав впливу.

Брак титулу, який би обов'язував чи уповноважував особу до вчинення дій у чужих справах $\epsilon$ не тільки однією з головних передумов ведення чужих справ без доручення, він $є$ також однією 3 головних рис зазначеної інституції.

Ведення чужих справ без доручення служить, таким чином, визначенню правових відносин, що виникають між тим, хто веде чужу справу і зацікавленою особою у випадках, коли ці відносини виникли з вже існуючих договірних відносин або іншого правового титулу. В цьому контексті, на думку доктора В.Драпали, можна шукати функціональних аналогій між negotiorum gestio i інститутом безпідставного збагачення. Слід також зазначити, що поява правового титулу під час дій гестора є єдиною з подій, що впливають на існуюче зобов'язальне правове відношення ведення чужих справ без доручення. Підставою для цього може бути перетворення зазначених відносин в договірні відносини (ст. 756 ЦК Польщі) або також припинення цих відносин в обсязі, в якому наступна дія гестора вміщується в обтяжуючих його обов'язках або належних йому повноваження ${ }^{2}$.

В конструкції ведення чужих справ без доручення передумова браку правового титулу досить виразно повязана з передумовою волі у діях на користь іншої особи з метою примноження такої користі.

Обидві ці риси свідчать про свідому й добровільну (motu proprio) діяльність гестора в чужій справі. В деяких європейських правових системах елемент добровільності діяльності висунутий на перше місце в діяльності без правового титулу.

Аналіз проблематики відсутності правового титулу для ведення чужих справ без доручення слід розпочати зі звернення до прийнятої польським законодавцем термінології. Вже у ст. 115 кодексу зобов'язань для описання цієї передумови negotiorum gestio використано термін «без доручення», ця термінологія була запозичена ще з римського права (gestio sine mandatu) ${ }^{3}$. Формула civilis negotiorum gestio застосовувалася у випадках, коли не виступало mandatum (що розумівся як контракт) і не можна було у зв'язку з цим застосовувати actio mandati. Ведення чужої справи було вираженням добровільної, спонтанної волі з допомоги близькій особі. Довоєнна доктрина виходила

\footnotetext{
${ }^{1}$ Hajberda, J. (2005). Koncepcja prowadzenia cudzych spraw bez zlecenia w kodeksie zobowiązań z 1933 roku na tle wcześniejszych rozwiązań europejskich. Czasopismo prawno - hystoryczne (Kraków), LVII, 1, 231.

${ }^{2}$ Drapała, P. (2010). Prowadzenie cudzych spraw bez zlecenia. Warszawa: Konstrukcja prawna, 91.

${ }^{3}$ Ludwiczak, W. (1960). Prowadzenie cudzych spraw bez zlecenia. Wybrane zagadnienia. Warszawa, 61.
} 
3 широкого розуміння формули «без доручення» як браку будь-яких уповноважень або обов'язків ведення чужих справ, що виникають $з$ договору, закону або інших джерел. Слід зазначити з цього приводу, що з того часу не було спроб зміни термінології і тому в попередніх проектах прийнятого у 1964 році Цивільного кодексу Польщі не було запропоновано інших формулювань поняття «без доручення». Однак між поняттями «без доручення» у кодексі зобов'язань і Цивільному кодексі $є$ певна різниця. Не стосується вона визначення браку правового титулу для ведення справи. У статті 752 ЦК Польщі законодавець скористався формулою «без доручення». Цей вираз сліз визначити як вкрай вузький (правовий титул може виникати не лише 3 доручення і не лише 3 договору) i дуже неточний. Як слідує 3 подальших рішень у випадках negotiorum gestio можемо мати справу також тоді, коли правовий титул існує, але гестор своїми діями виходить за межі своїх прав або обов'язків. Аналізуючи термінологію ЦК Польщі, можна дійти висновку, що negotiorum gestio це не ліше діяльність у чужій справі «без доручення», але й при виконанні зазначених передумов також діяльність «поза дорученням».

Відповідно до аналізу судових рішень у справах, що виникають з ведення чужих справ без доручення, умовою застосування приписів ЦК Польщі, що стосуються negotiorum gestio, $\epsilon$ відсутність яких-небудь правових підстав для здійснення діяльності, іншими словами - брак доручення, уповноваження, зобов'язання, правового обов'язку, що виникає з закону чи цівільного правовідношення. Ці приписи мають характер субсидіарний, оскільки мають застосовуватись тоді, коли правовідношення між сторонами не врегульовано в інший спосіб, а особливо обов'язок зазначених дій не виникає з якогось правового титулу ${ }^{1}$.

Так, зокрема, у Рішенні Вищого Суду від 17 квітня 2015 р. зазначено, що брак доручення означає відсутність жодного правового титулу - обов'язку, уповноваження, правомочності для ведення чужої справи, незалежно від того, з чого вони виникають: чи 3 правочину, чи 3 якогось іншого джерела (правових норм, рішень суду чи адміністративних актів) ${ }^{2}$.

Це підтверджується і іншими рішеннями судів різних інстанцій. Так, у рішенні Апеляційного Суду в Лодзі конструкція ведення чужих справ без доручення має застосовуватися виключно тоді, коли ведення чужої справи не випливає з правового відношення, яким пов'язані сторони. Джерелом таких правовідносин може бути договір, закон, рішення відповідного уповноваженого органу або односторонній правочин. Приписи статті 752 ЦК Польщі можуть бути застосовані лише у таких ситуаціях, у яких діяльність гестора в чужому інтересі не має під собою жодної правової підставиㄹ.

Українські суди у своїх рішеннях стосовно ведення чужих справ без доручення підтримують таку ж позицію. Так, у Постанові Вищого господарського суду України від 11 березня 2014 року зазначається, що дії гестора щодо запобігання попередженню, усунення або зменшення небезпеки настання невигідних майнових наслідків здійснюються ним за власною ініціативою, а не у зв'язку з укладенням договору доручення чи іншого цивільно-правового договору, а також відповідні дії не мають бути пов'язаними з виконанням службових чи інших, покладених відповідно до вимог закону, обов'язків ${ }^{4}$.

Той, хто веде чужу справу повинен діяти з власної волі ${ }^{5}$. У зв'язку з тим, що застосування норм про ведення чужих справ без доручення виключає існування правового титулу на втручання у правову сферу іншої особи, а титул цей може виникати також з норм права, в літературі, а також у судовій практиці підкреслюється, що інституція ведення чужих справ без доручення не може бути

\footnotetext{
${ }^{1}$ Lewandowska, E. (2012). Glosa do uchwały Sądu Najwyższego z dnia 20 stycznia 2010, III CZP 125. Studia Prawnoustrojowe, 17, 119-127.

${ }^{2}$ Wolters Kluwer (2015). Wyrok Sądu Najwyższego z dnia 17 kwietnia 2015 r. III CSK 272/14. Pojęcie ,braku zlecenia" w przyypadku prowadzenia cudzych spraw. Tekst orzeczenia pochodzi ze zbiorów Sądu Najwyższego $<$ https://sip.lex.pl/orzeczenia-i-pisma-urzedowe/orzeczenia-sadow/iii-csk-272-14-pojecie-braku-zlecenia-wprzyypadku-521804058> (2020, травень, 15).

${ }^{3}$ SAOS (2015). Wyrok Sadu Apelacyjnego w Łodzi z dnia 6 maja 2015 <https://www.saos.org.pl/judgments/157786> (2020, травень, 15).

${ }^{4}$ Protocol.ua (2014). Постанова ВГСУ від 11.03.2014 року у справі №5002-6/2091-2012

$<$ https://protocol.ua/ru/postanova_vgsu_vid_11_03_2014_roku_u_spravi_5002_6_2091_2012/> (2020, травень, 15).

${ }^{5}$ Sąd Najwyższy (1956). Orzeczenia Sądu Najwyższego z dnia: 3 grudnia 1956 r., I CR 211/55, 12 lipca 1978 r., IV CR 124/78, 9 marca 2004 r., I CK 576/03, 30 czerwca 2005 r., IV CK 784/04, 20 stycznia 2007 r., IV CSK 221/06, 20 stycznia 2010 r., III CZP 125/09, 29 listopada 2012 r., V CSK 568/11.
} 
застосована для обходу норм зобов'язального права (наприклад, ст. 376376 § 1, ст. 441 §, ст. 518 , 676,828 § 1 Кодексу цивільного Польщі) або для послаблення їх дії${ }^{1}$.

Яскравою ілюстрацією може у цьому контексті слугувати судова справа, що була на розгляді Господарського суду Донецької області.

Позивач, Дочірнє підприємство «Донецький облавтодор» Відкритого акціонерного товариства «Державна акціонерна компанія «Автомобільні дороги України», м. Покровськ, Донецька область, звернувся до господарського суду Донецької області з позовом до відповідача, Служби автомобільних доріг у Донецькій області, м. Краматорськ, Донецька область, про стягнення суми фактично понесених витрат у розмірі 166248,00грн.

В обгрунтування позовних вимог позивач посилається на те, що ним протягом лютого 2017 року були виконані роботи з зимового утримання автомобільних доріг загального користування місцевого значення Краснолиманського району у Донецькій області на загальну суму 166248,00грн, які не були передбачені договором №2-13 від 09.02.2016, та просить стягнути з відповідача витрати за проведені роботи як фактично понесені в майнових інтересах відповідача на підставі ст.ст. 1158, 1160 Цивільного кодексу України.

Відповідач проти позову заперечує, посилаючись на те, що наявність чинного на момент виконання робіт договору № 2-13 від 09.02.2016 виключає можливість застосування до правовідносин сторін глави 79 Цивільного кодексу України, адже спірний період виконання робіт був врегульований та визначений, в тому числі щодо обов язків з зимового утримання позивачем відповідної ділянки - автомобільних доріг загального користування місцевого значення Краснолиманського району у Донецькій області, саме в договірному порядку.

Розглядаючи цей спір, суд зазначає, що нормативне обгрунтування позову не розцінюється судом як підстава позовних вимог, якою $є$ фактичні обставини, якими позивач обгрунтовує свої вимоги. Водночас зауважує, що предметом позову є стягнення фактичних витрат позивача при вчиненні ним дії в майнових інтересах іншої особи - відповідача, без його доручення, отже, для задоволення заявлених позивачем вимог є необхідним встановлення обставин, які б свідчили про наявність передбачених законом підстав для відшкодування фактично понесених витрат згідно 3 приписами Глави 79 Цивільного кодексу України.

Доводячи наявність обставин, з якими закон пов язує право на відшкодування фактичних витрат, позивач посилається на виконання ним в майнових інтересах відповідача без його доручення протягом січня-лютого 2017 робіт з зимового утримання автомобільних доріг загального користування місцевого значення Краснолиманського району у Донецькій області на загальну суму $166248,00 г$ гн.

Водночас, складений та підписаний позивачем в односторонньому порядку акт виконаних будівельних робіт за лютий 2017 (ф. КБ-2в) на суму 166248,00грн (том 1, арк. справи 27-41) містить посилання на договір від 09.02.2016 №2-13 як на підставу виконання робіт, отже, не розцінюються судом як докази виконання позивачем дій за власною ініціативою, а не узв`язку з укладеним сторонами та чинним на час виконання спірних робіт договором.

Отже, судом встановлено, що дії позивача з виконання спірних робіт були здійснені ним не за власною ініціативою, як того вимагає ст.1158 Цивільного кодексу України, а були пов язані з укладенням договору №2-13 від 09.02.2016 та виконанням обов`язків згідно з Порядком взаємодії у випадках виникнення несприятливих погодних умов та надзвичайних ситуацій на автомобільних дорогах загального користування.

При цьому, суд зазначив, що перевищення позивачем обсягів здійснених за замовленням відповідача робіт за договором №2-13 від 09.02.2016 не дає підстав само по собі вважати виконання таких робіт позивачем вчиненням дій в майнових інтересах відповідача без його доручення в розумінні ст. 1158 Цивільного кодексу України ${ }^{2}$.

В доктрині і судовій практиці склалося практично одностайне розуміння правового титулу.

Римське право визначало титул як законну підставу виникнення прав ${ }^{3}$. Титульне володіння за римським правом покладалось в основу більшості способів набуття права власності. У сучасній

\footnotetext{
${ }^{1}$ Sąd Najwyższy (2009). Wyrok Sądu Najwyższego z dnia 16 września 2009, I CSK 35/09.

2 ЗаконОнлайн (2019). Справа № 905/148/19 <https://zakononline.com.ua/court-decisions/show/82129402>

(2020, травень, 15).

3 Дождев, Д. В. (2006). Римское частное право. Москва: НОРМА, 405.
} 
юридичній літературі правовий титул розуміється переважно у контексті права володіння, зазвичай йдеться про те, що титульним володінням є таке, що має під собою правову підставу (титул), у якості якої може виступати, зокрема, договір ${ }^{1}$.

Відповідно до позиції Верховного Суду України, безтитульне володіння - це фактичне володіння, яке не спирається на будь-яку правову підставу володіння чужим майном².

Підстави набуття права власності іменуються титулами власності, і являють собою юридичні факти, на підставі яких виникає право власності у конкретних осіб. Наприклад, підставами виникнення права власності можуть бути договори купівлі-продажу, міни, дарування, довічного утримання, заповіти, рішення суду ${ }^{3}$.

В польській правничій літературі посеред правових титулів, що є підставами ведення чужих справ, традиційно на першому місці називають договори $\mathrm{i}$ односторонні правочини ${ }^{4}$. Як уже зазначалось раніше, використана законодавцем формула «без доручення» не може ототожнюватися лише з відсутністю відносин доручення або іншого роду договірних стосунків. Правовий титул діяльності в чужому інтересі може також виникати з будь-якого дійсного правочину (одностороннього, двостороннього, багатостороннього). Але це вже $є$ темою для іншого дослідження.

Висновки. Підсумовуючи проведене дослідження, можемо зробити висновок про те, що відповідно до аналізу судових рішень усправах, що виникають з ведення чужих справ без доручення, умовою застосування приписів ЦК Польщі, що стосуються negotiorum gestio, $\epsilon$ відсутність яких-небудь правових підстав для здійснення діяльності, іншими словами - брак доручення, уповноваження, зобов'язання, правового обов'язку, що виникає з закону чи цівільного правовідношення. Ці приписи мають характер субсидіарний, оскільки мають застосовуватись тоді, коли правовідношення між сторонами не врегульовано в інший спосіб, а особливо обов'язок зазначених дій не виникає з якогось правового титулу. Українські суди у своїх рішеннях стосовно ведення чужих справ без доручення підтримують таку ж позицію. Так, у Постанові Вищого господарського суду України від 11 березня 2014 року зазначається, що дії гестора щодо запобігання попередженню, усунення або зменшення небезпеки настання невигідних майнових наслідків здійснюються ним за власною ініціативою, а не у зв'язку з укладенням договору доручення чи іншого цивільно-правового договору, а також відповідні дії не мають бути пов'язаними з виконанням службових чи інших, покладених відповідно до вимог закону, обов'язків.

\section{References:}

1. Lewandowska, E. (2012). Glosa do uchwały Sądu Najwyższego z dnia 20 stycznia 2010, III CZP 125 [Gloss to the resolution of the Supreme Court of January 20, 2010, III CZP 125]. Studia Prawnoustrojowe [Studia Prawnroboustowe], 17, 119-127. [in Polish].

2. Hajberda, J. (2005). Koncepcja prowadzenia cudzych spraw bez zlecenia w kodeksie zobowiązań z 1933 roku na tle wcześniejszych rozwiązań europejskich [The concept of handling someone else's affairs without a commission in the Code of Obligations of 1933 against the background of earlier European solutions]. Czasopismo prawno - hystoryczne (Kraków) [Legal and hystory magazine (Kraków)], LVII, 1. [in Polish].

3. Kruszyńska-Kola, J. (2016). Prowadzenie cudzych spraw bez zlecenia jako wyraz zachowań altruistycznych [Conducting someone else's affairs without an order as an expression of altruistic behavior]. Ruch prawnyczy, ekonomiczny i socjologiczny [Legal, economic and sociological movement], LXXYIII, 1. [in Polish].

4. Drapała, P. (2010). Prowadzenie cudzych spraw bez zlecenia [Conducting other people's tasks without an order]. Warszawa: Konstrukcja prawna. [in Polish].

5. Ludwiczak, W. (1960). Prowadzenie cudzych spraw bez zlecenia. Wybrane zagadnienia [Conducting other people's tasks without an order. Selected Issues]. Warszawa. [in Polish].

\footnotetext{
${ }^{1}$ Харитонов, Є. О., Саніахметова, Н. О. (2003). Цивільне право Украӥни. Підручник. Київ: Істина, 337.

${ }^{2}$ Protocol.ua (2019). Володіння майном на підставі певного юридичного титулу, тобто таке, щяо спирається на будь-яку правову підставу володіння чужим майном, виключає застосування набувальної давності $<$ https://protocol.ua/ua/vp_vs_volodinnya_maynom_na_pidstavi_pevnogo_yuridichnogo_titulu_tobto_take_shcho_spi raetsya_na_bud_yaku_pravovu_pidstavu_volodinnya_chugim_maynom_viklyuchae_zastosuvannya_nabuvalnoi_davn osti_(vp_vs_sprava_910_17274_17_14_05_19)/> (2020, травень, 15).

${ }^{3}$ Борисова, В., Спасибо-Фатєєва, І., Яроцький, В. (ред.) (2007). Цивільне право Украйни. Кийв: Юрінком Інтер, 1. $<$ http://www.big-lib.com/book/44_Civilne_pravo_Ykraini_tl> (2020, травень, 15).

${ }^{4}$ Ludwiczak, W. (1960). Prowadzenie cudzych spraw bez zlecenia. Wybrane zagadnienia. Warszawa, 61.
} 
6. SAOS (2015). Wyrok Sadu Apelacyjnego w Łodzi z dnia 6 maja 2015 [Judgment of the Court of Appeal in Lodz, dated May 6, 2015] <https://www.saos.org.pl/judgments/157786 $\geq$ (2020, травень, 15). [in Polish].

7. Sąd Najwyższy (2009). Wyrok Sądu Najwyższego z dnia 16 września 2009, I CSK 35/09 [Judgment of the Supreme Court of 16 September 2009, I CSK 35/09]. [in Polish].

8. Wolters Kluwer (2015). Wyrok Sądu Najwyższego z dnia 17 kwietnia 2015 r. III CSK 272/14. Pojęcie „braku zlecenia" w przyypadku prowadzenia cudzych spraw. Tekst orzeczenia pochodzi ze zbiorów Sądu Najwyższego [Judgment of the Supreme Court of 17 April 2015. III CSK 272/14. The concept of "no order" in the case of someone else's business. The text of the judgment comes from the collections of the Supreme Court] $<$ https://sip.lex.pl/orzeczenia-i-pisma-urzedowe/orzeczenia-sadow/iii-csk-272-14-pojecie-braku-zlecenia-wprzyypadku-521804058> (2020, травень, 15). [in Polish].Bobrova, D. (1997). Nedohovirni zobovyazannya u proekti Tsyvilnoho kodeksu Ukrayiny 1996 [Non-contractual obligations in the draft Civil Code of Ukraine 1996]. Ukrayinske pravo [Ukrainian law], 3, 180. [in Ukrainian].

9. Protocol.ua (2019). Volodinnya maynom na pidstavi pevnoho yurydychnoho tytulu, tobto take, shcho spyrayetsya na bud-yaku pravovu pidstavu volodinnya chuzhym maynom, vyklyuchaye zastosuvannya nabuvalnoyi davnosti [Possession of property on the basis of a certain legal title, ie one that is based on any legal basis for possession of another's property, excludes the application of the statute of limitations] $<\mathrm{https}$ //protocol.ua/ua/vp_vs_volodinnya_maynom_na_pidstavi_pevnogo_yuridichnogo_titulu_tobto_take_shcho_ spiraetsya_na_bud_yaku_pravovu_pidstavu_volodinnya_chugim_maynom_viklyuchae_zastosuvannya_nabuvalnoi _davnosti_(vp_vs_sprava_910_17274_17_14_05_19)/> (2020, травень, 15). [in Ukrainian].Dozhdev, D. V. (2006). Rimskoye chastnoye pravo [Roman private law]. Moscow: NORMA. [in Russian].

10. Zubar, V. M. (2001). Zobovyazannya, shcho vynykayut z vedennya chuzhykh sprav bez doruchennya: dysertatsiya na zdobuttya naukovoho stupenya kandydata yurydychnykh nauk [Obligations arising from the conduct of other people's affairs without a power of attorney: a dissertation for the degree of Candidate of Law]. Kyiv: NAS of Ukraine VM Institute of State and Law Koretsky. [in Ukrainian].

11. Sąd Najwyższy (1956) [Supreme Court (1956)]. Orzeczenia Sądu Najwyższego z dnia: 3 grudnia 1956 r., I CR 211/55, 12 lipca 1978 r., IV CR 124/78, 9 marca 2004 r., I CK 576/03, 30 czerwca 2005 r., IV CK 784/04, 20 stycznia 2007 r., IV CSK 221/06, 20 stycznia 2010 r., III CZP 125/09, 29 listopada 2012 r., V CSK 568/11 [Judgments of the Supreme Court of December 3, 1956, I CR 211/55, July 12, 1978, IV CR 124/78, March 9, 2004, I CK 576/03, June 30, 2005, IV CK 784/04, 20 January 2007, IV CSK 221/06, 20 January 2010, III CZP 125/09, 29 November 2012, V CSK 568/11]. [in Polish].

12. Pestruyev, D. M. (2017). Rehulyuvannya vedennya chuzhykh sprav bez doruchennya u tsyvilnomu zakonodavstvi Polshchi [Regulation of conducting other people's affairs without a power of attorney in the civil legislation of Poland]. Naukovo-praktychnyy zhurnal Chasopys tsyvilistyky [Scientific journal Journal civil law], 25, 57-62. [in Ukrainian].

13. Pestruyev, D. M. (2019). Formuvannya kontseptsiyi pravovoho rehulyuvannya vedennya sprav inshoyi osoby bez yiyi doruchennya v Ukrayini ta Polshchi [Formation of the concept of legal regulation of another person's affairs without his / her instructions in Ukraine and Poland]. Naukovo-praktychnyy zhurnal Chasopys tsyvilistyky [Scientific journal Journal civil law], 25, 41-47. [in Ukrainian].

14. Pestruyev, D. M. (2018). Psykholohichna osnova vedennya chuzhykh sprav bez doruchennya u polskomu pravi [Psychological basis of conducting someone else's business without a power of attorney in Polish law.]. Shereshevski chytannya Problemy tsyvilno-pravovoho zakhystu prav vlasnykiv u suchasnykh umovakh intehratsiynoho rozvytku Ukrayiny: materialy vseukrayinskoyi naukovo-praktychnoyi konferentsiyi, prysvyachenoyi 85-richchyu akademika V.V. Lutsya (Odesa, 7 hrudnya 2018 roku) [Shereshevsky readings "Problems of civil law protection of owners' rights in modern conditions of integration development of Ukraine": materials of the all-Ukrainian scientific-practical conference dedicated to the 85th anniversary of Academician VV Lutsya (Odessa, December 7, 2018)]. Odesa: Feniks, 75-78. [in Ukrainian].

15. Protocol.ua (2014). Postanova VHSU vid 11.03.2014 roku u spravi №5002-6/2091-2012 [Resolution of the HCSU of March 11, 2014 in the case №5002-6 / 2091-2012]<https://protocol.ua/ru/postanova_vgsu_vid_11_03_2014_roku_ u_spravi_5002_6_2091_2012/> (2020, травень, 15). [in Ukrainian].

16. ZakonOnlayn (2019) [LawOnline (2019)]. Sprava №905/148/19 [Case № 905/148/19] $<$ https://zakononline.com.ua/court-decisions/show/82129402 $\geq$ (2020, травень, 15). [in Ukrainian].

17. Stavisskiy, P. R., Kharitonov, Ye.O. (1979). Obyazatelstva iz vedeniya del bez porucheniya i nekotoryye smezhnyye obyazatelstva $\mathrm{v}$ sovetskom grazhdanskom prave [Obligations from conducting business without a mandate and some related obligations in Soviet civil law]. Problemy sotsialisticheskoy zakonnosti [Problems of Socialist Rule of Law], 4, 104-111. [in Russian].

18. Kharitonov, Y. O. (1980). Obyazatelstva, voznikayushchiye iz vedeniya del bez porucheniya, v sovetskom grazhdanskom prave: avtoreferat dissertatsii na soiskaniye nauchnoy stepeni kandidata yuridicheskikh nauk [Obligations arising from conducting business without a mandate in Soviet civil law: abstract of a dissertation for the degree of candidate of legal sciences]. Odessa: OGU imeni I. I. Mechnikova. [in Russian].

19. Kharytonov, Y. O. (2014). Systema zobovyazan, shcho vynykayut vnaslidok vidvernennya shkody, za Tsyvilnym kodeksom Ukrayiny [The system of obligations arising from the prevention of damage, according to the Civil 
Code of Ukraine]. Aktualni problemy pryvatnoho prava Ukrayiny: Zbirnyk statey do yuvileyu doktora yurydychnykh nauk, profesora Nataliyi Semenivny Kuznyetsovoyi [Current issues of private law of Ukraine: Collection of articles for the anniversary of Doctor of Law, Professor Natalia Semenovna Kuznetsova], 461-480. [in Ukrainian].

20. Kharytonov, Y. O., Saniakhmetova, N. O. (2003). Tsyvilne pravo Ukrayiny. Pidruchnyk [Civil law of Ukraine. Textbook]. Kyiv: Istyna. [in Ukrainian].

21.Borysova, V., Spasybo-Fatyeyeva, I., Yarotskyy, V. (ed.) (2007). Tsyvilne pravo Ukrayiny [Civil law of Ukraine]. Kyiv: Yurinkom Inter, 1.<http://www.big-lib.com/book/44_Civilne_pravo_Ykraini_tl $>$ (2020, травень, 15). [in Ukrainian]. 